\title{
Five-Year Cumulative Incidence of Unhealthy Diet in Adult Croatian Population: the CroHort Study
}

\author{
Jasna Pucarin-Cvetkovićc',2, Mario Šekerija ${ }^{2}$ and Nataša Janev Holcer ${ }^{1}$ \\ ${ }^{1}$ University of Zagreb, School of Medicine, »Andrija Štampar« School of Public Health, Department of Environmental and \\ Occupational Medicine, Zagreb, Croatia \\ 2 Croatian National Institute of Public Health, Zagreb, Croatia
}

\begin{abstract}
A B S T R A C T
This study investigated 5-year cumulative incidence of unhealthy dietary habits across various gender and age groups within the CroHort study, a repeated cross-sectional survey of Croatian adults. The results monitoring the frequency of certain foodstuffs consumption indicate that $10.6 \%$ of examinees (10.9\% of men, and $9.1 \%$ of women) reported worsening of their dietary habits in 2008 as compared to 2003. The cumulative incidence of unhealthy diet was higher in men than in women, and was highest in younger age-groups (18-34 years), both in men and women. The public health programmes should be strengthened in a way which would put a special emphasis on education of younger adults, especially males, on nutrition health impact and healthy diet principles.
\end{abstract}

Key words: dietary habits, adult population, CroHort Study

\section{Introduction}

Today, non-communicable diseases (NCDs) account for $60 \%$ of all projected deaths worldwide - i.e. an estimated 35 million people died of NCDs. Some $80 \%$ of NCD deaths occur in low- and middle-income countries. The top five NCDs are heart disease, stroke, cancer, chronic respiratory diseases and diabetes. There exists strong scientific evidence that healthy diet and adequate physical activity play an important role in the prevention of these diseases. Furthermore, it is estimated that approximately $80 \%$ of heart diseases, strokes and type 2 diabetes cases, as well as $40 \%$ of cancers, can be prevented through inexpensive and cost-effective interventions that address primary risk factors ${ }^{1}$. In most countries, national surveys indicate an excessive fat intake, low fruit and vegetable intake and an increasing problem of obesity faced by the national population, not only shortening the life expectancy, but also lowering the quality of life ${ }^{2}$.

Specific recommendations for a healthy diet propose an increased consumption of fruit, vegetables, legumes, nuts and grains, and well as salt, sugar and fat intake putdown. It is also advisable to choose unsaturated fats over the saturated ones and to eliminate trans-fatty acids. Dietary habits improvement is a societal, not just an individual problem. Therefore, it demands a population- -based, multi-sector, multi-disciplinary, and culturally relevant approach ${ }^{3}$.

It can be recognised even from the early childhood that food intake varies by gender. Dietary surveys carried out in Europe have highlighted the differences in food consumption between men and women, with men having higher intakes of meat products, alcohol and sugar, and lower intakes of fruit, vegetables and low-fat products as compared to women. In some respects, these choices make women's diets more consistent with current recommendations than those of men ${ }^{4}$.

This paper aims at determining a 5-year cumulative incidence of unhealthy dietary habits across different age and gender groups.

\section{Subjects and Methods}

This study makes the principal use of the sample examined on the occasion of 2003 Croatian Adult Health Survey $(\mathrm{CAHS})^{5}$, re-examined on the occasion of 2008 (CroHort) ${ }^{6}$. Namely, 2008 Croatian Health Survey was a re-survey of 2003 CAHS sample, the subjects examined 
TABLE 1

CHANGES IN DIETARY HABITS IN A 5-YEAR PERIOD DISPLAYED BY AGE GROUPS

\begin{tabular}{|c|c|c|c|c|}
\hline \multirow[b]{2}{*}{$\begin{array}{l}\text { Age groups embraced } \\
\text { by } 2003 \text { CAHS* }\end{array}$} & \multicolumn{2}{|c|}{$\begin{array}{c}2003 \\
\text { Healthy diet } \\
(\mathrm{N}=2763 ; \mathrm{M}=828 ; \mathrm{F}=1935)\end{array}$} & \multicolumn{2}{|c|}{$\begin{array}{c}2003 \\
\text { Unhealthy diet } \\
(\mathrm{N}=461 ; \mathrm{M}=187, \mathrm{~F}=274)\end{array}$} \\
\hline & $\begin{array}{c}2008 \\
\text { Healthy diet }\end{array}$ & $\begin{array}{c}2008 \\
\text { Unhealthy diet }\end{array}$ & $\begin{array}{c}2008 \\
\text { Healthy diet }\end{array}$ & $\begin{array}{c}2008 \\
\text { Unhealthy diet }\end{array}$ \\
\hline $\begin{array}{c}18-34 \\
(\%)\end{array}$ & $\begin{array}{c}258 \\
(85.4 \%)\end{array}$ & $\begin{array}{c}44 \\
(14.6 \%)\end{array}$ & $\begin{array}{c}53 \\
(74.6 \%)\end{array}$ & $\begin{array}{c}18 \\
(25.4 \%)\end{array}$ \\
\hline $\begin{array}{c}35-64 \\
(\%)\end{array}$ & $\begin{array}{l}1351 \\
(89.0 \%)\end{array}$ & $\begin{array}{c}167 \\
(11.0 \%)\end{array}$ & $\begin{array}{c}199 \\
(80.9 \%)\end{array}$ & $\begin{array}{c}47 \\
(19.1 \%)\end{array}$ \\
\hline $\begin{array}{c}65+ \\
(\%)\end{array}$ & $\begin{array}{c}861 \\
(91.3 \%)\end{array}$ & $\begin{array}{c}82 \\
(8.7 \%)\end{array}$ & $\begin{array}{c}114 \\
(79.2 \%)\end{array}$ & $\begin{array}{c}30 \\
(20.8 \%)\end{array}$ \\
\hline
\end{tabular}

*Croatian Adult Health Survey

both in 2003 and 2008 thereby being considered as a single cohort composed of 3,224 individuals.

As a part of 2003 CAHS questionnaire, five nutrition-related questions used in this study (types of fat used in food preparation; fat in milk products; fruit eating habits; preserved meat products eating habits and adding salt) were posed. Subjects were considered to have unhealthy dietary habits if complying with at least three of the following: regularly intake of food prepared using animal fat, regular consumption of full-fat $(3.2 \%)$ milk and milk products, low consumption of fruits, preserved meat products consumption at least twice a week, and food salting prior to its tasting ${ }^{7}$. All analyses were made using SAS 8.02.

\section{Results}

Changes in dietary habits, seen in a 5-year period and displayed by age, are presented in Table 1 . Independent of gender, the highest cumulative incidence of unhealthy dietary habits was recorded among younger (146/1000) and the lowest one among elder examinees (87/1000).

A higher 5-year cumulative incidence of unhealthy dietary habits was recorded among younger men (219/1000) and younger women (122/1000). In all of the examined age groups, a higher 5-year cumulative incidence of unhealthy dietary habits was observed among men then among women (Table 2).

\section{Discussion}

The results based on the CHA data gathered throughout 2003 and 2008 to the effect of monitoring the frequency of certain foodstuffs consumption, indicate that $10.6 \%$ of examinees have witnessed decline in their dietary habits as compared to 2003 data. Age-based research revealed younger men (aged 18-34) to have the highest 5-year cumulative unhealthy diet incidence $219 / 1000$ citizens; the same applies for women of the same age (122/1000 citizens). Furthermore, monitoring of frequency of certain foodstuffs consumption revealed almost half (47\%) of younger men and a quarter $(25.4 \%)$ of younger women to be in custom of almost regularly consuming preserved meat products, as opposed to elderly (i.e. those aged +65 ) who do not tend to pursue such a dietary path. On the occasion of both surveys, regular fruit consumption was more often witnessed in elder representatives of both sexes.

Smaller families, an increased number of elderly, an enhanced communication and information flow, less home cooking, an increased consumption of industrially prepared food, and an increased trend of eating out are only some of the factors affecting the modern way of life. According to our research output underpinned by the data on household-based consumption gained by the Surveys, a slight change in dietary habits of Croatian population members can be noted as well. This trend has also mirrored in the increase of refined industrial foodstuff con-

TABLE 2

A 5-YEAR CUMULATIVE INCIDENCE OF UNHEALTHY DIETARY HABITS IN PERSONS ESTABLISHED TO PURSUE A HEALTHY DIET IN 2003

\begin{tabular}{|c|c|c|c|c|c|c|c|c|}
\hline & \multicolumn{4}{|c|}{$\begin{array}{c}\text { Male } \\
\text { (years) }\end{array}$} & \multicolumn{4}{|c|}{$\begin{array}{l}\text { Female } \\
\text { (years) }\end{array}$} \\
\hline & $\begin{array}{l}<18-34 \\
(\mathrm{~N}=73)\end{array}$ & $\begin{array}{c}35-64 \\
(\mathrm{~N}=453)\end{array}$ & $\begin{array}{c}65+ \\
(\mathrm{N}=302)\end{array}$ & $\begin{array}{c}\text { Total } \\
(\mathrm{N}=828)\end{array}$ & $\begin{array}{l}<18-34 \\
(\mathrm{~N}=229)\end{array}$ & $\begin{array}{c}35-64 \\
(\mathrm{~N}=1065)\end{array}$ & $\begin{array}{c}65+ \\
(\mathrm{N}=641)\end{array}$ & $\begin{array}{c}\text { Total } \\
(\mathrm{N}=1935)\end{array}$ \\
\hline Cases & 16 & 68 & 33 & 117 & 28 & 99 & 49 & 176 \\
\hline 5-year cumulative incidence per 1000 & 219 & 150 & 109 & 143 & 122 & 93 & 76 & 91 \\
\hline $95 \% \mathrm{CI}$ & $124-314$ & $117-183$ & $74-145$ & $118-165$ & $80-165$ & $76-110$ & $56-97$ & 78-104 \\
\hline
\end{tabular}


sumption, i.e. the consumption of products having a higher salt content, especially that of the preserved meat products, sugars and trans-fatty acids ${ }^{8,9}$, unanimously viewed as risk factors for the onset of cardiovascular, let alone other chronic non-communicable diseases.

A study just like ours was conducted in Danish adult population (aged 15-90) both in 1995 and 1998. Changes in dietary habits reflected in an increased consumption of salads and raw vegetables, rice and fish, while the frequency of meat, potato, fresh fruit and low-fat milk consumption was lower. The results of the study indicated the needs for changes in dietary habits, which are to be viewed upon as a dynamic process calling for continuous investigation into, and monitoring of, such changes, as well as for population-tailored education on the importance of a healthy diet ${ }^{10}$.

The results of the study presented herein follow the footsteps of the similar research conducted across Europe, even though a number of European studies have been designed so as to monitor dietary habits and foodstuff consumption frequency relative of educational and socioeconomic background of the study participants. In order to consolidate the results and simplify the demonstration of interrelations between socio-demographic variables and dietary habits, the study by Dynesen et $\mathrm{al}^{11}$ monitored the consumption of foodstuffs in adult population using the healthy diet index. The results revealed the female population to more often consume fruit and vegetables, but less often meat, as compared to men. The analysis of the healthy diet index revealed healthier dietary patterns to be more often pursued by women, better educated persons, elderly and persons living in larger households. Educational background and other socio-demographic determinants were revealed to have a greater influence on switching to healthy diet when it comes to men than when it comes to women.

Prättälä et al. ${ }^{12}$ have also pointed towards substantial differences in gender-based dietary habits across Finland, Estonia, Lithuania and Latvia. The study results indicated that men, irrespective of their educational background, are more in custom of eating meat, while highly educated women tend to eat more fruit and vegetables; this applies for all of the investigated countries mentioned above.

Conformant to ours and other studies quoted above, the Food and Drug Administration (FDA) has emphasised that younger men (aged 18-34) eat less fruit and vegetables as compared not only to elder men, but also to women of all ages. FDA has also come to the conclusion that healthy diet recommendations are strongly supported by women than by men, as well as by elderly than by younger population members. The compliance with these recommendations most often takes form of saturated fat avoidance and salt intake reduction ${ }^{13}$.

When investigating dietary habits and their health impact, the tendency of foodstuff grouping is not an uncommon practice. In line with the foregoing, van Dam et $\mathrm{al}^{14}$ identified three food consumption patterns: the »cosmopolitan« pattern (higher intakes of fried vegetables, salad, rice, chicken, fish, and wine), the »traditional « pattern (higher intakes of red meat and potatoes, and lower intakes of low-fat dairy and fruit), and the »refined-foods « pattern (higher intakes of French fries, high-sugar beverages and white bread, and lower intakes of whole-grain bread and boiled vegetables). Higher traditional pattern scores were associated with older age, as opposed to the higher refined-food scores which were associated with younger age; nevertheless, both of the aforementioned were associated with a lower educational level, cigarette smoking, less physical activity, and a higher body mass index.

Based on the study outcomes, Gary TC Ko et $\mathrm{al}^{15}$ have pointed out that the poorest dietary habits can be found across younger employed male population; however, they have also emphasised that younger and middle-aged populations are particularly receptive to educational influence; that is to say that educational messages on healthy diet at workplace are capable of more easily persuading them to improve their dietary habits, which is of a particular importance for public health.

Having regard to the recommendations brought by the Global Nutrition, Physical Activity and Health Strategy ${ }^{16}$ which seeks foundation in an efficient public health strategy oriented towards dietary habit changes to the effect of prevention of diet-related chronic communicable diseases, it is of the outmost importance to replace saturated and trans-fatty acids with non-hydrogenised ones, as well as to ensure the intake of at least $400 \mathrm{~g}$ of fruit and vegetables a day, reduce the intake of salted and sweetened products and be physically active at least 30 minutes a day. In 2007, the European Union came up with the strategic document driven by the initiative striving to reduce an excessive kitchen salt intake (known by the name of »White Paper on A Strategy for Europe on Nutrition, Overweight and Obesity «) ${ }^{17}$. In pursue of its efforts to improve dietary habits and overall health, the World Health Organisation, WHO Office for Europe, created the Second WHO Action Plan for Food and Nutrition Policy 2007-2012. This Second Action Plan addresses main public health challenges in the area of nutrition, food safety and food security, and deals with diet-related non-communicable diseases (particularly obesity), micronutrient deficiencies and food-borne diseases ${ }^{18}$.

It is hence crucial to implement public health preventative programmes tailored so as to raise awareness on the importance of healthy diet across any given age group, younger adults in particular. Another important public health mission is to educate the consumers and allow them to choose and decide wisely when shopping. That can be largely attained by virtue of specifically tailored campaigns, social marketing and declarations on energy, carbohydrate, fat, saturated fat and sodium contents, which also necessitates a close collaboration with the food industry.

\section{Acknowledgments}

This study was supported by the Croatian Ministry of Science, Education and Sport, Grant No. 108-10801350264 . 


\section{R E F E R E N C E S}

1. WORLD HEALTH ORGANIZATION/WORLD ECONOMIC FORUM, Report of a Joint Event. Preventing Non-communicable Diseases in the Workplace through Diet and Physical Activity. (WHO, WORLD ECONOMIC FORUM Geneva, 2008). - 2. WORLD HEALTH ORGANIZATION, Tasty, nutritional food adds years to life and life to years, accessed 14.06.2011. Available from: URL: http://www.euro.who.int/en/what-we-do/health-topics/disease-prevention/nutrition. - 3. WORLD HEALTH ORGANIZATION, Diet, accessed 14.06.2011. Available from: URL: http: /www.who.int/topics/diet/en/. — 4. COX ND, ANDERSON SA. Food choice. In: Gibney JM, MARGETTS MB, KEARNEY MJ, ARAB L (Eds) Public Health Nutrition (Blacwell Science, Oxford, 2004). - 5. VULETIĆ S, PO LASEK O, KERN J, STRNAD M, BAKLAIĆ Z, Coll Antropol, 33 (suppl. 1) (2009) 3. - 6. IVIČEVIĆ-UHERNIK A, VULETIĆ S, KERN J, DEĆKOVIĆ-VUKRES V, MIHEL S, ERCEG M, PRISTAŠA I, Coll Antropol 36 suppl 1 (2012) 3. - 7. KERN J, STRNAD M, CORIC T, VULETIC S, BMJ 331 (2005) 208. - 8. REPUBLIC OF CROATIA - CENTRAL BUREAU OF STATISTICS, Statistical Yearbook 2004 (Central Bureau of Statistics, Department of Statistical Information and Documentation, Republic of Croatia, Zagreb, 2004). - 9. REPUBLIC OF CROATIA - CENTRAL BUREAU OF STATISTICS, Statistical Yearbook 2004 (Central Bureau of Statistics, Department of Statistical Information and Documentation, Republic of Croatia, Zagreb, 2004). — 10. HARALDSDÓTTIR J, HALKJAER
J, HOLM L, STENDER S, ASTRUP A, Ugeskrift Laeger, 161 (1999) 5028. - 11. DYNESEN AW, HARALDSDÓTTIR J, HOLM L, ASTRUP A, Eur J Clin Nutr, 57 (2003) 1586. - 12. PRÄTTÄLÄ R, PAALANEN L, GRINBERGA D, HELASOJA V, KASMEL A, PETKEVICIENE J,. Eur J Public Health, 17 (2007) 520. — 13. Food and Drug Administration — FDA, Health and Diet Survey: Dietary Guidelines Supplement-Report of Findings (2004 \& 2005), (FDA, New Hampshire Ave, 2008), accessed 10.06.2011. Available from: URL: http://www.fda.gov/food/scienceresearch/researchareas/ consumerresearch/ucm080331.htm. - 14. van DAM MR, GRIEVINK L, OCKÉ CM, EDITH JM FESKENS JME, Am J Clin Nutr, 77 (2003) 1156. - 15. KO TCG, CHAN CNJ, CHAN LWL, Asia Pac J Clin, 16 (2007) 757. - 16. WORLD HEALTH ASSMBLY, Global Strategy on Diet, Physical Activity and Health, accessed 15. 06. 2011. Available from: URL: http:/ /www.who.int/gb/ebwha/pdf_files/WHA57/A57_R17-en.pdf. - 17. COMMISSION OF THE EUROPEĀN COMMUNITIES, White paper on A Strategy for Europe on Nutrition, Overweight and Obesity related health issues, (Commission of the European Communities, Brussels, 2007), accessed 15. 06. 2011. Available from: http://ec.europa.eu/health/ph_determinants/life style/nutrition/documents/nutrition wp en pdf - 18. WORLD HEALTH ORGANIZATION, European action plan for food and nutrition policy 2007-2012, (WHO, Copenhagen, 2008).

\section{J. Pucarin-Cvetković}

University of Zagreb, School of Medicine, »Andrija Štampar « School of Public Health, Rockefellerova 4, Zagreb, Croatia e-mail: jpucarin@snz.hr

\section{PREHRAMBENE NAVIKE: 5-GODIŠNJA KUMULATIVNA INCIDENCIJA - CroHort STUDIJA}

\section{S A ̌̌ E T A K}

Cilj ovog istraživanja bio je utvrditi 5-godišnju kumulativnu incidenciju loših prehrambenih navika prema spolu i dobnim skupinama. Na temelju podataka Hrvatske kohortne studije kardiovaskularnog zdravlja (CroHort) prikupljenih tijekom 2003. i 2008. godine kojom je praćena učestalost potrošnje pojedinih namirnica, dobiveni rezultati upućuju na lošije prehrambene navike u 10,6\% ispitanika u odnosu na njihovu prehranu 2003. godine. Istraživanja prema dobnim skupinama ukazala su da muškarci, ali i žene mlađe životne dobi, imaju najveću 5-godišnju kumulativnu incidenciju loših prehrambenih navika. Stoga je nužno povećati javnozdravstvene programe s ciljem edukacije odraslih o utjecaju prehrane na zdravlje i principima pravilne prehrane, s posebnim naglaskom na mlađe dobne skupine odrasle populacije. 